\title{
Human Flows, Trade and Security: The Changing Role of the Chumbi Valley in the Himalayan Region
}

\author{
By Karubaki Datta*
}

\begin{abstract}
Extensive land and maritime networks have crisscrossed Asia for centuries providing the basis for encounters between diverse people and cultures. The Chumbi Valley of Tibet at the tri junction between Bhutan, India and China (Tibet) is one such corridor that has made possible a stream of human migration from Tibet to the south as well as the exchange of religious and political ideas leading to the formation of the states of Bhutan and Sikkim (a part of India since 1974) in the 17th century. The role of the Chumbi Valley has been changing over time. The British after coming to India were allured by the prospects of trade with the Himalayan region, Tibet and beyond, through this route. They were also concerned for the security of their Indian empire from Russia beyond Tibet. The aftermath was the British expedition of 1904 that forced open the valley to British trade marts. Lately, China has also become interested in the valley out of strategic motivations. China's rising military modernization, rapid force deployment and expanding communication network in the region has become a matter of concern for India. China's presence in Chumbi Valley not only gives her proximity to India's North-East and particularly the Siliguri corridor but ultimately gives passage to Nepal and Bhutan.
\end{abstract}

\section{Introduction}

It is common knowledge that specific Geographical factors of a certain area shape the history and politics of the communities based on that particular region. This is particularly true of India's North region where the mighty Himalayan range, stretching over 25,000 km from Kashmir in the West to Arunachal Pradesh in the East, provide India with a natural and most formidable line of defense. In the early twentieth century, Lord Curzon had visualized the Himalayan region of Ladakh, Sikkim, Bhutan and Northeast frontier as an 'inner defense line for India protected by a Tibetan buffer region' 1 . The protective role of the Himalayas has been enhanced by the vast expanse of the Tibetan plateau to its North, the elevation of which is approximately that of an ordinary mountain range. In his description of the region, K.M. Pannikar had written that "the mountainous area to the North of India has to be considered strategically as one great plateau of $15,000 \mathrm{ft}$. (c.460 $\mathrm{mt}$.) above sea level and the southern ramparts, an invulnerable range of an average height of $20,000 \mathrm{ft}$ (c.600 mt.). The enclosed area is $50,000 \mathrm{mi}^{2}$ (c.93,

\footnotetext{
*Associate Professor and Director, Centre for Himalayan Studies, North Bengal University, District- Darjeeling, India.

${ }^{1}$ As quoted by K. Warikoo, Himalayan Frontiers of India : Historical, Geo Political And Strategic Perspectives, (London, Routledge, 2009), Preface xi.
} 
$050 \mathrm{~km}^{2}$ ), frightening and formidable in its geographical features, an arid waste, windswept and waterless where trees do not grow' ${ }^{1}$. So, in spite of the new sophisticated advancements in weapon and communication technologies, the traditional importance of the Himalayas as the basic land frontier and natural barrier has not been diminished.

In addition to India, the other countries that share boundaries with this mountain range are Tajikstan, Afghanistan, China (erstwhile Tibet) Pakistan, Nepal, Bhutan and Myanmar. Due to its proximity to South and West Asia, the region has emerged as a distinct geo-political entity stimulating global attention and interest. The geographical features of the region have certainly been among the determinants of the interstate relations and security issues of the region.

However, its imposing geographical features have not prevented the region from being a complex hub of cultural interaction, migration, overland trade and communication. Chumbi Valley, in the Eastern Himalayas has been one such gateway through which this interaction between India and Tibet has taken place for a very long period of time. Its function has changed over the years and from being the passage between Tibet, India and the Himalayan states of Bhutan and Sikkim for migration and commercial exchanges, it has now become a part of China and thereby a point of convergence of the defense and security interests of both India and China. All this naturally lends a unique geostrategic importance to this region.

The present paper highlights this changing role of the Chumbi Valley in the Eastern Himalayas. It is primarily based on secondary sources. In addition to some contemporary accounts and travelogues of the period, relevant information is drawn from gazetteers, books and articles. Some contemporary information with regard to trade through Nathu-la is collected from newspapers and websites.

\section{The Region as it Used to Be ...}

The region where Chumbi Valley is situated has passed through several political transformations. Though in China now, it used to be a part of erstwhile Tibet, which after the Chinese takeover in 1959 became TARC, i.e. Tibet the Autonomous Region of China. It shares border with Sikkim in the West and Bhutan in the East. Sikkim is a part of India now but till 1973 it was an independent kingdom. It is $5 \mathrm{~km}$ from the Siliguri corridor - in the Northern part of the state of West Bengal in India which is commonly described as the chicken neck that connects India to Northeast India and also to Nepal and Bhutan. Because of its location, the Chumbi Valley is of geostrategic importance to both the giant states of India and China. It is often described as the 'dagger drawn at India's heart'.

By virtue of its location, Chumbi Valley has also been vital in shaping the history of the region. It has been the corridor through which migration has taken place from the region of Tibet to the south and vice versa, carrying with

${ }^{1}$ Ibid. 
it the socio-cultural influences of one country to the other. It has also been the stage where some great powers have interacted with each other to establish control over the trade and politics of the region (Figure 1).

Figure 1. Chumbi Valley and its Neighborhood

\section{CHUMBI VALLEY}

PASSES AND TRADE ROUTES

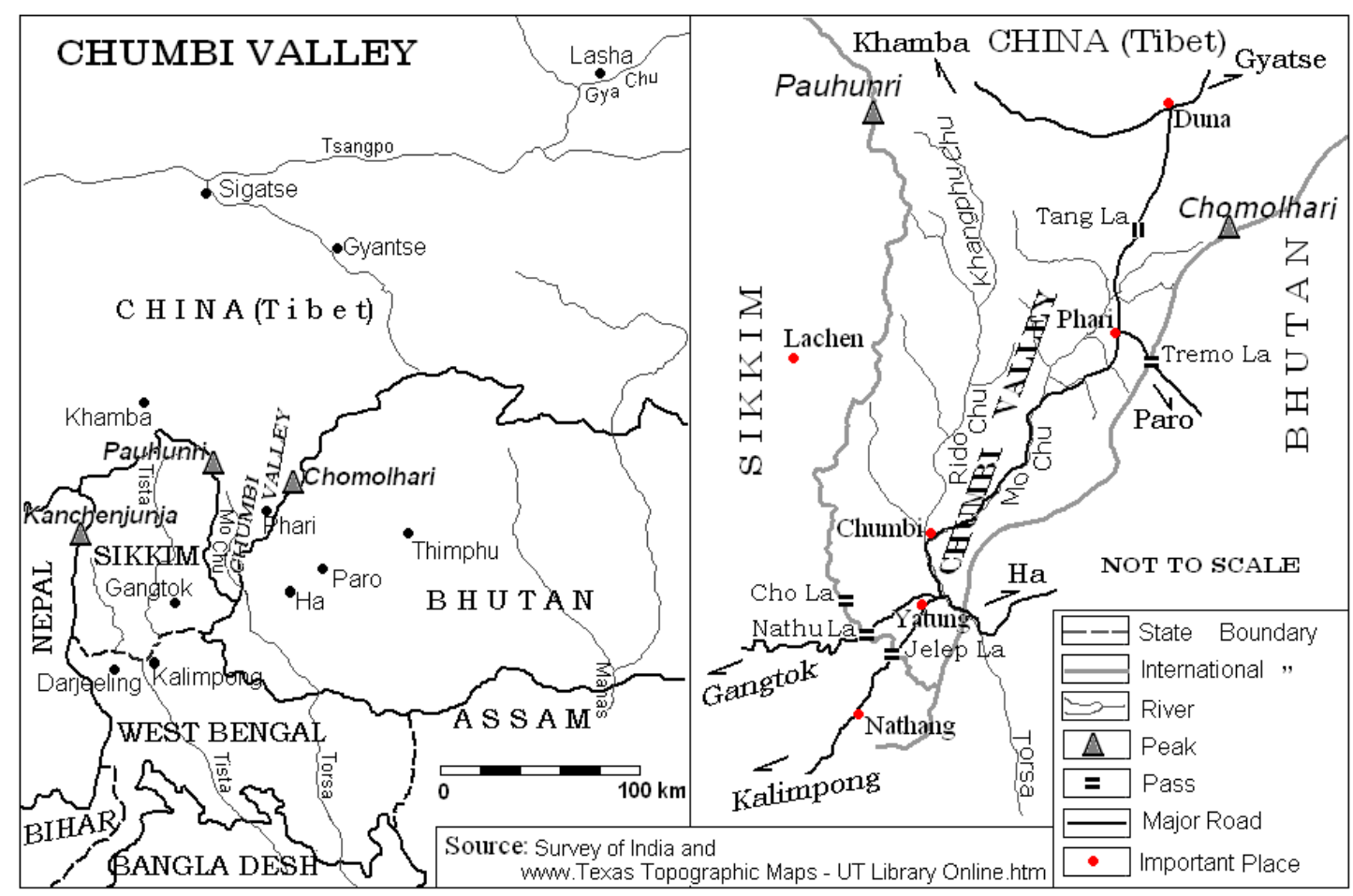

Source: Survey of India and www.TexastopographicMaps-UTLibraryOnline.htm, courtesey Dr. D.P.Boot, Cartographer, Centre for Himalayan Studies, North Bengal University.

To begin with a description of the valley itself, the two passes of Nathu-la in Sikkim (14,000 ft.) and Jelep-la (14,390 ft. meaning the 'smooth and beautiful pass') in Kalimpong of Darjeeling are the two most important gateways to the valley. Of these two, Jelep-la used to be the most frequented of all the passes opening out into the Mochu valley near Chumbi. The road from there leads directly to Lhasa - the capital of Tibet. Two other less frequented passes are Yak-la (14,400 ft.) which is close to Nathu-la and Cho-la $(14,550 \mathrm{ft}$. ) which leads more directly to Chumbi than any of the above and was formerly the main route from Sikkim to Phari in Chumbi. ${ }^{1}$

"Along the trade route followed by the traveler, however, the eye is held (to the right side of the trail) for several days of the march by the immense mountain mass of Chomo-lhari, the Queen of the Divine Hills, a mountain sacred to all Tibetans and situated along the Tibet-Bhutan border at an elevation of nearly $24,000 \mathrm{ft}$. "The fascination of Tibet lies in its utter

${ }^{1}$ H.H.Risley, The Gazetteer of Sikkim. Calcutta: Bengal Press, 1894. (Reprinted, Delhi: Low Price Publications, 1999), 3. 
bleakness and wilderness, .... once the traveler has climbed onto the plateau...not a bush, let alone a tree, breaks the monotony of the windswept plains, until he reaches the town of Gyantse.' 1

In between the two was the cold and windy Phari -at an elevation of well over 14,000 $\mathrm{ft}$. Phari was described as an 'eerie town' consisting of a rude collection of stone and sod houses 'dominated by a huge grim looking fort.' Even though it seemed an altogether discouraging place to live' it was a market town, always bustling with activities throughout the year. The discouragement it invoked to its visitors was because of its dirt. The town has been described by travelers as the highest, windiest, dirtiest town in the world...'. This bleak town was always cold, even during the summer, so cold, in fact that 'despite the refuse of hundreds of years in the narrow spaces between the houses, there was little or no odor because of the dry, bitterly cold climate., ${ }^{2}$

Phari is also called the head of the Chumbi Valley. The route from there leads to Gyantse and then to Lhasa itself. Gyantse was the seat of an important Tibetan administrative district with population of about 5,000 people. This was also the meeting place of the three travel routes. To the western side along the river Nyang was situated Shigatse, Tibet's second city and the seat of the Panchen Lama. Towards the east over the six thousand ft. Katro-la was situated Lhasa - the sacred as well as the forbidden capital of Tibet.

"Near the city of Gyantse...could be found numerous farms and villas surrounded by fair sized groves of poplar and willow trees and 'acres of dwarf iris'. Situated in the middle of a fertile valley, entirely surrounded by hills reaching to $16,000 \mathrm{ft}$. and crisscrossed with irrigation channels, Gyantse (itself over 13,000 ft. high) had from time immemorial become one of Tibet's leading communities as all the trade from the east up to Northwest Tibet and Ladakh and also to Nepal, India and Bhutan passed through its portals." 3 Gyantse possessed a particularly 'busy and elaborate' bazaar that was rich in colour, human interest and activity. One visitor gave a vivid description of the place in 1949: "the goods are spread out on the ground or on rough table... and the merchants often sit under large umbrellas or awnings, where they enjoy gossiping as much as making sales.....here one could find Chinese brick tea, Tibetan salt and soda, dried fruits, jewelry, dyes, hand-woven Tibetan rugs, and bowls made of silver birch transported from Bhutan". 4

Through this route, at the end of which lay the Chumbi Valley, was carried on the entire southward bound Tibetan trade with Bengal or Sikkim. In 1962, following the Indo China war both the routes were closed down. After several years, the trade has commenced once again through Nathu-la in Sikkim.

\footnotetext{
${ }^{1}$ David Macdonald, Touring Touring in Sikkim and Bhutan. Kalimpong: Thackef \&Spink, 1933, 5-6.

${ }^{2}$ H. Louis Fader, Called from obscurity: The life and times of a true son of Tibet, God's humble son from Poo: Gergen Dorje Tharchin, vol.2, (Kalimpong, Tibet Mirror Press: 2004), 81.

${ }^{3} \mathrm{H}$. Louis Fader, Called from obscurity: The life and times of a true son of Tibet, God's humble son from Poo: Gergen Dorje Tharchin, vol.2, (Kalimpong, Tibet Mirror Press: 2004), 81.

${ }^{4}$ H. Louis Fader, Called from obscurity: The life and times of a true son of Tibet, God's humble son from Poo: Gergen Dorje Tharchin, vol.2, (Kalimpong, Tibet Mirror Press: 2004), 86.
} 


\section{Migration from Tibet to Sikkim}

The influence of Tibet on the demography and culture of Sikkim has been profound and this influence has travelled mainly through the Chumbi Valley. The Valley, at one point of time was regarded as part of Sikkim itself. Sikkim was situated just next to Tibet but in this mountainous region with little or no communication and very few inhabitants, there was hardly any concept of a border between the two countries. Therefore, in absence of any demarcated border or even an accurate account of the region, it is difficult to come to a definite conclusion regarding the actual extent of the state. In the report of his political mission to Bhutan in 1864, Ashley Eden, noticed that 'Sikkim, though a very petty state then was formerly a fair sized country reaching from the Arun river on the west to the Taigon pass on the east, from Tibet on the north to Kissingunge in Purneah on the south.' Risley further clarifies that it included the Mochu valley. ${ }^{1}$ Since the river Mochu is variously known as Amochu or Chumbi, it is implied that Chumbi Valley was very much a part of Sikkim. Even though it is difficult either to accept or refute this argument, it is true that Sikkim has lost a bulk of its original territory. One portion that has become part of West Bengal now is Darjeeling that was handed over to the British by the king of Sikkim himself in 1835. On the whole, it is possible that Chumbi Valley at one point of time was indeed a part of Sikkim. The kings of Sikkim often spent the summers there.

The boundary between Sikkim and Tibet was 'clearly defined' for the first time by the Britain -China Convention of 17.03.1890. According to clause I of the Convention, this boundary was defined as the "crest of the mountain range separating the waters following into Sikkim Teesta and its effluents from the waters flowing into the Tibetan Mochu and northwards into other rivers of Tibet. The line commences at mount Gimpochi on the Bhootan frontier and follows the above mentioned water parting to the point where it meets Nepaul territory'. ${ }^{2}$

Situated next to Tibet, Sikkim has been profoundly influenced by Tibet in terms of both its population and its culture. This influence developed mainly through the Kham-pa or Kham-ba-immigrants from the Tibetan province of Kham, commonly called Bhutias.

The original inhabitants of Sikkim were the Rongs or the Lepchas and, most probably some Limbus and Mangars. The Bhutias were later migrants but thanks to their dominant nature, they managed to establish their supremacy over the original inhabitants. These Bhutias, representing Tibeto-Burman stock, introduced Tibetan culture in the region which was a combination of pastoralism and settled agriculture and of course Tibetan Buddhism. Docile and unassertive, the Lepchas were easily relegated to a secondary position. They were gradually converted into Buddhism and brought into the fold of the

\footnotetext{
${ }^{1}$ H.H Risley. The Gazetteer of Sikkim. (Calcutta: Bengal Press, 1894) (Reprinted, Delhi: Low Price Publications, 1999).

${ }^{2}$ R. Moktan Sikkim-Darjeeling Compendium of Documents, (Kalimpong, R.Moktan,' Sumaralaya', 2004), Article I of Britain-China Convention, 17.03.1890, 27.
} 
ruling community over time while the Limbus, being unable to adjust to the new social reality imposed by the Bhutias ,had to migrate out of Sikkim. ${ }^{1}$

It is tough to reconstruct the history of Sikkim prior to the $17^{\text {th }}$ century because the original inhabitants of the region did not have any written script and therefore no written account. In the vast body of Tibetan literature, one comes across only a few references of the very early phase of introduction of Buddhism but these are abstract in character and mixed with myths and legends. Being so, it does not provide a clear picture of the course of events.

On the whole, it appears that Bhutia migration took place in phases, one of the earliest immigrants being one Khye Bumsa. He had established a cordial relation with the Lepchas and was even blessed by the Lepcha wizard for a son. The descendants of Khye Bumsa are divided into six families. With Khye Bumsa came other Tibetans or khampas who founded the 8 fields or the tribe of eight respectable names. These are the 14 original main families of Tibetan origin in Sikkim.

Besides these, there are other families of Tibetan origin which form the raichhung or the 'little families'. They came to Sikkim at various points in time since the establishment of the monarchy and are divided into 8 groups. Like the 14 original families they also enjoy some religious and social privileges particularly pertaining to entry to monasteries. While their exact place of origin is not mentioned specifically, at least one family viz. the sTod-pa or TumnsTod-pa are so called from their having first settled in Tumu or Upper Mochu Valley. After them came others, like the Chumbi-pa, immigrant from Kham in Tibet and Ha in Bhutan, to the lower reaches of the Mochu near Chumbi. The history of immigration from the Chumbi region is indicated by the name of the group itself. ${ }^{2}$

The most important impact of Bhutia migration was the consecration of the first Chogyal or king of Sikkim in 1642.Legend has it that three monks from Tibet arrived in Sikkim (one of them from South Tibet i.e. Chumbi Valley through Darjeeling), met at Yoksam and selected Phuntsog Namgyal, a great grandson of Khye Bumsa as the king. Henceforth Buddhism was proclaimed as the state religion and a spree of monastery building activity set in Buddhism in this region was basically of Tibetan type but the process of intermingling with local beliefs and rituals gave it a particularly Sikkimese character. Buddhism remained the state religion till the merger of the state with India in 1974. Monarchy was abolished then but even after that the Bhutias managed to maintain their dominance in all spheres of life. Even now, as a result of the influx of Tibetan refugees in the state, the impact of Buddhism and Tibetan culture has remained prominent in the state. As stated above, the hill regions of the district of Darjeeling of West Bengal belonged to Sikkim till

\footnotetext{
${ }^{1}$ Chie Nakane, "A plural society in Sikkim: A study of the interrelations of Lepchas, Bhutias and Nepalis" in Caste and kin in Nepal, India and Ceylon, Anthropological studies in Hindu Buddhist contact zones, ed. Christoph Von Furer Haimendorf (Delhi, Asia Publishing House, 1966), 220.

${ }^{2}$ H.H Risley, The Gazetteer of Sikkim. (Calcutta: Bengal Press, 1894)(Reprinted, Delhi: Low Price Publications, 1999, 28-30.
} 
1835 when it was handed over to the British by the king of Sikkim. By virtue of its historical tie with Sikkim, Darjeeling also came to share some of the demographic and cultural characteristics of Tibet. There were some Bhutias in Darjeeling but there was neither monarchy in this part of India, nor did the region have any state religion.

As in Sikkim, there used to be migration from the Chumbi Valley to Bhutan as well. The border between Bhutan and Chumbi Valley is formed by the Great Himalayan range, the highest peak being the Chomolhari $(23,997 \mathrm{ft}$.). The access to Bhutan from all directions is difficult due to its various river systems that cut through the country in a North-South direction. The rivers are wild and impossible to navigate in the rainy season. There are some passes on Bhutan's border with Tibet but only three are of significance. Of these the one which is historically the most important is the route from Paro and Ha valleys in western Bhutan into the Chumbi Valley in Tibet. Streams of Tibetan migration have taken place through this route and these Tibetans were the ones to shape the history, culture and politics of Bhutan as well.

Unlike the case of Sikkim, in Bhutan we do not have any record of the specific branches of Tibetans who migrated into the country. However it is known that Tibetans have entered the country in waves. The political history of Bhutan is closely interlinked with its religious history which is actually the history of branches of monastic Buddhism imported from Tibet by these Tibetans in phases.

The earliest introduction of Tibetan Buddhism through Tibetan migrants is difficult to identify but there are references to the descendants of a member of Lhasa Royal family who had fled to Bhutan in the $10^{\text {th }}$ century. From the $12^{\text {th }}$ century onwards, one comes across references to various sub-sects of Tibetan Buddhism in Bhutan.In the following centuries, most of the elite families in Bhutan claimed descent from these lamas (Buddhist monks) belonging to these sects. ${ }^{1}$ The route through which they migrated is not specifically known but their concentration and dominance in the western Bhutan highlands points to the possibility of them having taken the route through Chumbi Valley.

The protagonist of modern Bhutan was the prominent Drukpa lama, Ngwagang Namgyal who came to the region in 1616 and unified almost the whole country. Most probably, he also came from the west as it documented that he first established his political and religious authority in western Bhutan and only towards the end of his life, in 1652, his authority was established in parts of eastern Bhutan as well. ${ }^{2}$ The political system that he founded bore a strong resemblance to that of Tibet under the Dalai Lama. The system, headed by both the Dharma and the Deb Rajas, continued till 1907, only to be replaced by the monarchical system. Buddhism continues to be the state religion even now even though absolute monarchy has been replaced by constitutional monarchy and democracy by the promulgation of the new constitution of July, 2008. In other words, the influence of Tibet and Tibetan culture on Bhutan has

${ }^{1}$ Leo Rose, Politics of Bhutan, (Ithaca, Cornell University Press, 1970), 24-25.

${ }^{2}$ Leo Rose, Politics of Bhutan, (Ithaca, Cornell University Press, 1970), 24-25. 
been profound and this has been possible due to Tibetan migration, a large part of which has taken place through the Chumbi Valley.

\section{Trade through the Chumbi Valley}

One motivation of human movement through the Chumbi Valley was definitely trade. Initially there was a regular small scale, informal trans-border trade carried on by the locals. The growth of trade between Tibet and India through the Chumbi Valley on a much larger scale was a later development of the British period. The two passes of Nathu-la and Jelep-la became the entrepots of this trade.

By the $19^{\text {th }}$ century, Tibet had become a forbidden country for all the people of non-Buddhist origin. No formal permission was given to the British or to any person of western or non Buddhist origin to carry on official trade or to open any trading mart inside Tibet. Informal trade however was indeed carried on along the border. Trans-border trade began to develop in a more systematic manner after the handover of Darjeeling to the British in 1835 by the king of Sikkim. The earliest reference to Tibetan traders is found in the account of Campbell. In 1848 he met a party of Tibetans en route to Darjeeling Rennie also gives an idea about how negligible this trade could have been before this period. In 1865, Rennie wrote:

"At the present time, no extent of trade exists and what does, is carried on chiefly on sheep used as pack animals. Wool is the principal commodity brought from Thibet, cotton and tobacco being taken back in exchange. Ponies also, gold, silver, precious stones, coarse woolen and China goods are sometimes brought over from Thibet. The traders generally pass from Thibet about November before the snows set in, and return in spring after the melting of the snow has commenced: passes in the mountains being impracticable in the interval. Judging however, from the number of Thibetians seen about Darjeeling during the period I was there, they evidently either remain until later periods of the year or come across during the summer months as well". 1

It was actually in the second half of the $19^{\text {th }}$ century that the trade began to expand. The political as well as economic interests of the British rulers of India in the region and their attempt to surge through this route to Tibet brought out the strategic location of the Chumbi Valley. The growh of trade through this route and the opening up of Tibet by the British were the two significant developments of the late $19^{\text {th }}$ century.

Immediately after the annexation of Darjeeling in 1835, the British rulers explored the possibilities of trans-border trade in the region. Reports were prepared by officers in Darjeeling in 1864 and 1873 on the possibilities of new

${ }^{1}$ David Field Rennie, Bhotan and the story of the Dooar War, (London: John Murray, 1866), 376. 
trade routes and destinations along with all other related information like trading items and impediments, if any. The reports pointed out the imperfect communication system as the basic obstacle to the development of trade and even justified the construction of railways for the purpose.

There are also specific references to Tibetan traders in those reports. The report of 1873 mentions few such traders but it is not made clear whether the people who traded were actually Tibetans from the heartland of the country or people living in the border areas of Sikkim. In any case, it is clear that these people had access to Phari in Chumbi valley and they had already started exploring the possibilities of trade with Darjeeling. On the $28^{\text {th }}$ of October 1873 Edgar also met some traders who were on their way to Darjeeling where they planned to exchange coarse blanket for tobacco. At Keu Laka, he met a family of herds-men from whom he learnt that they had supplied butter and cream cheese to the markets of Darjeeling and Lhasa. These markets were mainly in the need for beef, butter and cheese of the herds of cow of the Phari region of Chumbi Valley. By the turn of the century, Tibetan trade ventures in the region became quite frequent. Darjeeling grew as a coveted hill station and the scope of trade and business also expanded. It is reported that around the last quarter of the $19^{\text {th }}$ century Tibetan traders visited the Sunday market of the town regularly. For instance, R.D. O'Brien, in his description of Darjeeling wrote:

'... if you pick up the very dirtiest man or woman you can find, be sure he or she is a Thibetan trader. These people cross the snowy range annually about November, bringing with them rock salt, yak tails, sometimes gold dust, musk and other commodities of various kinds besides sheep, goats in large flocks. These they sell and return laden with tobacco, broadcloth, piece goods, and other commodities in February, March. During their stay in Darjeeling they live in small tents which they bring with them. Their favorite encamping ground is the Lebong spur.'

The items imported from Tibet were horse, blankets, tea, turquoise, wool, musk, oxtails, musical instruments and shoes while the items exported to Tibet included tobacco, indigo and kutch. The Tibetan traders took the route starting from Cho-la, Yek-la, Nathu-la, Cumra, and Dangas. All this met in Sikkim through which they entered Darjeeling via Gangtok and Dikeeling.

However, trade between Darjeeling subdivision and Tibet was not to last long. In the course of time, after the annexation of Kalimpong in $1865^{2}$, the Indo-Tibetan trade via Darjeeling gradually shifted to the newly developed town of Kalimpong which was more suitably located for the caravans coming

\footnotetext{
${ }^{1}$ R.D. O'Brien, Darjeeling: The Sanatorium of Bengal and its Surroundings (Calcutta, 1883). The book is generally accepted as one of the oldest descriptions of Darjeeling.

${ }^{2}$ Now a part of Darjeeling district, originally it was a part of the state of Sikkim .Later Bhutan occupied this and after Bhutan's defeat in the Anglo Bhutanese War, it was handed over to the British in 1865 who then joined it to the district of Darjeeling.
} 
down from Jelep-la and Nathu-la. The most important article of trade at this time was Tibetan coarse wool which began to be imported in huge amount. The growth of Kalimpong as another hill town of Darjeeling owed much to this Tibetan trade through Jelep-la. Warehouses (godowns) came up in Kalimpong where this wool was stored. While there were Tibetan traders who carried the articles to Kalimpong and even stayed in the town, there were also several Indian traders, most of them Marwaris ${ }^{1}$, who traded with this coarse wool and reexported it to the south of Bengal and sometimes to other parts of India and even abroad. This rise of the wool trade changed the character of the Darjeeling hills and particularly that of Kalimpong.

The scope of trade from Sikkim to Tibet by the British was defined by the Sikkim -Tibet Convention on 5.2.1893. Before that in 1861, in the context of the Treaty of Tumloong the British Government extracted full liberty of commerce between the British and Sikkim subjects and some other concessions regarding commercial transactions. The right to open roads through Sikkim for trade was also ensured. It was a matter of time that the British would step out into the Chumbi Valley from Sikkim, and the British presence in the region was authorized in the Convention of 1893. A trade mart was to be established at Yatung on the Tibetan side of the frontier that would be open to all the British subjects for trade. The government of India was to be free to send officers to reside there in order to watch the conditions of the British trade while the British subjects were also at liberty to travel between the frontier and Yatung, to reside in Yatung and to rent houses and godowns for their own accommodation and the storage of their goods. British subjects would be free to carry on the trade in general and some tax exemptions were also announced by the Convention. ${ }^{2}$ The foothold that the British gained in the Chumbi Valley as a result of this convention culminated by the Great Britain - Tibet Convention on 07.09.1904 consequent to the Younghusband Expedition of the same year. A new set of trade regulations between Great Britain and Tibet known as the Anglo-Tibetn Regulation came into being in 1914. After India gained independence from the British in 1947, the Panchsheel Agreement of 1954 between China and India gave a further boost to trade. After the agreement -trade passed through both the passes of Nathu-la and Jelep-la but since Sikkim was not yet a part of India, it could not be mentioned in the agreement; instead it was regulated through an Indian Trade Agent who issued trade permits. Jelep-la was the principal gateway for the famous Tibetan wool trade while Nathu-la was primarily the centre of military activities as well as of high value commodities like petrol, auto parts, expensive watches etc. that yielded high profit.

The route to Kalimpong through Jelep-la was mainly frequented by people who wanted to visit this part of India for various reasons. Along with traders came other types of visitors as well, from the sacred to the profane, the monks

\footnotetext{
${ }^{1}$ A traditional trading community from Rajasthan state of Western India.

${ }^{2}$ Sikkim - Tibet Convention 05.12.1893 as quoted by R Moktan. Sikkim: Darjeeling: Compendium of Documents. Kalimpong: Sumaralaya, 2004, 29-30.
} 
and the pilgrims, students, politicians, and activists, and even some common people who wanted to make India their home.

Tibet's relations with China was complicated from the 1911 Republican Revolution onwards and particularly worsened in the 1950s. During this period the movement of people also increased. Rich Tibetans sent their children to schools in Darjeeling and Kalimpong, rented houses and even settled down in these towns. In 1959 when the $14^{\text {th }}$ Dalai Lama Himself fled Tibet and took refuge in India, He was followed by thousands of his countrymen, most of whom followed this trodden path through Chumbi Valley to enter India. The less trodden path through the Cho-la mountain pass of the Chumbi Valley was used by the Royal family of Sikkim who still owned palaces there. ${ }^{1}$

\section{From Chumbi to Lhasa - The British Expedition of 1903 -04}

The Younghusband Expedition of 1903-04 to Tibet was an event of farreaching significance for the history of this region. Not only did this expedition forced to open the doors of the forbidden land of Tibet for the first time but it also changed the political equation between Tibet and China. In the aftermath of this expedition, Tibet started to tilt more towards the British and ultimately severed its relation with China. ${ }^{2}$

Actually the British interest in Tibet stemmed from its concerns for the security of its Indian empire. Tibet was a 'forbidden land' and there was hardly any information available about its relations with Russia or actual political status vis. a vis. China. The first mission was sent as early as 1782 under Bogle and several more followed in course of the next century. Younghusband expedition was the culmination of this. The decision to send the expedition was taken by Lord Curzon out of his concern for the Northern frontier of the British India particularly from the threat of Russian advance. In the beginning of the $20^{\text {th }}$ century, there were rumours of exchange of gifts and envoys between Russia and the $13^{\text {th }}$ Dalai Lama. Accounts of such exchanges have been recorded by Kawaguchi who himself was suspected to be a secret agent of the Japanese or the British or both of them. ${ }^{3}$ This inspired a great fear among the ruling circles of British India. This fear was further aggravated by unconfirmed stories of a secret Russian agreement with China, according to which it was said that China had permitted Tibet to orientate towards Russia in exchange of Russia's assent to permit China to take over areas of eastern or Chinese

\footnotetext{
${ }^{1}$ Pema Wangchuk, "India, China and the Nathu La, Converting Symbolism into Reality." Institute of Peace and Conflict Studies (IPCS) 202, (January 2013), http://www.ipcs.org/pdf_ file/issue/IB202-CRP-Pema-NathuLa.pdf. accessed on December 22, 2014.

${ }^{2}$ Motives and consequences of Younghusband expedition have been discussed in many history books. Fader has discussed the event thoroughly in pp.176 -198 of Chapter 16 -'Central Asian Geopolitics and the Tibetan Church at Kalimpong' of his above mentioned book Called from Obscurity.

${ }^{3}$ He was a Zen Buddhist monk who had travelled and studied in Tibet for three years including a fourteen month stay in Lhasa. There were suspicions regarding his actual motives and he has been accused of spying by some scholars but this is a debatable issue.
} 
Turkestan and eastern Mongolia. Curzon became convinced that there was a secret undertaking, if not a secret treaty between China and Russia about Tibet. Any possible Russian influence in Tibet, he feared, would pose a dangerous threat to the entire frontier of British India.

Convinced that the only way to prevent that was to send a British mission to Tibet, Lord Curzon submitted such a proposal to the Imperial Government in London. The objective was to establish a regular relation with Tibet. The initial plan was to send a 'pacific mission' to conclude a treaty of friendship and trade with Tibetan government.

In spite of the initial reluctance on part of the Home government, the Viceroy managed to get authorization to send the mission but only as far as Khamba Dzong in Chumbi Valley, a Tibetan fortress town just beyond the Sikkim border. The mission was led by Col. Younghusband with J.C. White, the Political Officer of Sikkim, as his second in command. The mission reached the Dzong in July 1903 but talks failed to lead to a mutually accepted agreement. This prompted Curzon to extract a reluctant permission from the Home Government to mount an expedition accompanied by a sizeable protective military contingent. The expedition proceeded to Lhasa but by then the $13^{\text {th }}$ Dalai Lama had already fled Lhasa to Urga, in Chinese Mongolia, and the British could not find any trace of Russian presence or activity in Lhasa.

The British force in absence of the Dalai Lama drafted the Lhasa Convention and got it signed by the Tibetan officials on $7^{\text {th }}$ September $1904 .^{1}$ The main features of the Convention called for opening of new trade marts at Gyantse and Gartok with a British trade agent to reside at each. No selling or leasing of Tibetan territory to any foreign power (aimed basically against Russia), and the imposition of an indemnity of 75 lakh Rs. on Tibet for Britain to be paid in 75 installments were also some of the terms of the agreement. The Chumbi Valley was to remain under the British until the indemnity was paid. ${ }^{2}$ The entire episode created so much embarrassment for the British that the treaty terms had to be ultimately modified, the indemnity payment period had to be reduced and the attached article had to be abandoned. In fact, many concessions that Curzon had extracted were nullified in effect by the British Government in course of the next few years. The most significant consequence was the resignation of Curzon himself. The Government, eager to prove to the world that it had no territorial ambition in Tibet and considered Tibet under the suzerainty of China took a policy of non-interference and withdrew all troops from the Chumbi Valley in 1908. However the British garrison continued in the trade marts. A new trade agreement was signed with China and all the trade marts at Gyantse, Gartok and Yatung would now be placed under the control of the Chinese officials. The Chinese promptly paid the British Rs. 25 lakh of indemnity in three annual installments and asserted their presence in the scene.

\footnotetext{
${ }^{1}$ Great Britain - Tibet Convention 07.09.1904, entire text quoted by R. Moktan, Sikkim: Darjeeling: Compendium of Documents. (Kalimpong: Sumaralaya, 2004), 32-35.

${ }^{2}$ Sir Francis Younghusband had himself described the entire expedition in India and Tibet, (London, John Murray, 1910, Reprint, Delhi, Low Price Publications, 1994).
} 
The Chinese control continued only till 1911 when their very presence in Tibet was eliminated following the Republican Revolution in China itself.

The post of British trade agent had already been authorized by the 1904 treaty. The British were permitted to maintain one trade representative in Tibet and for this purpose officers in charge with the majority of the troops stationed in Gyantse company of Indian infantry with two British was always present in Tibet, with merely a small detachment of them being kept at Yatung. The trade agency's headquarters itself was situated at Yatung and not at Gyantse despite the fact that the latter was a much larger town.

Between Yatung and Gyantse, a distance of about 140 miles was dotted every 10 to 15 miles with comfortable British built Dak Banglows available to both travelers and officials. This strategic trade route was jointly administered by both British and Tibetan trade agents in accordance with the Treaty of 1904 at Lhasa. The trade agents were normally stationed in the Tibetan towns of Yatung and Gyantse. In this point it should be clarified that the term "trade agents" is in a sense misleading because the British Trade Agency had little to do with trade matters. The agent was more of a vice consular or even a consul general. He was given this title of Trade Agent because he was appointed by the British Foreign Office due to the indefiniteness of the political relations between China and Tibet. As discussed above, the post had been sanctioned by the 1904 treaty signed between Tibet and Britain to terminate the Younghusband military expedition to Lhasa.

The Indian colonial functionaries began to draw schemes for further commercial linkage of Tibet with their Indian empire. Steps were also taken to establish this form of trade agency in the Tibetan town of Shigatse. Charles Bell, Settlement Officer in Kalimpong, proposed and surveyed the route to link the Valley to the Indian railway system. A railway track, about 50 miles long between the Gangetic plains and Chumbi Valley on the narrowest location across the Himalayas was proposed to be the commercial link of the Himalayan plateau to the industrial belt of Bengal. ${ }^{1}$ But this plan could not be realized as Curzon soon had to leave India.

\section{Chumbi Valley - The High Security Zone of Modern Times}

Lately, Chumbi Valley has assumed a different geostrategic importance and has become crucial from the perspective of Sino Indian relations. In the second half of the $20^{\text {th }}$ century, two new regimes emerged in the Asian scene The Peoples' Republic of China and the Indian Union which turned out to be two adversaries in terms of their ideologies as well as territorial interests. Within a few years, the two armies ended up clashing over the McMahon Line in the Eastern Himalayas ${ }^{2}$ in 1962. From 1965 onwards, instances of border

\footnotetext{
${ }^{1}$ A.C. Sinha, "Train to Chumbi Valley", On Occasions. Last modified December 27, 2004. http://acoomarsinha.blogspot.in/2004/12/train-to-chumbi-valley.html.

${ }^{2}$ McMahon Line is the disputed boundary between India and China. It was demarcated in 1916 in a tripartite convention between British India, China and Tibet in Simla, India. The region
} 
intrusions were reported on the Sikkim Tibet border and in 1965 PLA even launched a direct attack on the Indian armed forces at Nathu-la on the SikkimTibet border. ${ }^{1}$ Despite several rounds of talks taking place since then, the border issues have not been solved and the Indian policy towards the Dalai Lama and the Tibetan refugees is not well accepted by China. The two sides continue to maintain a frigid friendly relation and Chumbi Valley has become crucial for territorial ambition and security concern for both China and India respectively. The Valley is of great geostrategic importance to China because of its shared border with Sikkim and Bhutan. Mao ZeDong had once defined Tibet as the palm which had five fingers -Ladakh, Sikkim, Nepal, Bhutan and Arunachal Pradesh. ${ }^{2}$ With control over Tibet, the Chinese ambition is to bring these regions under its area of influence. The significance of Chumbi Valley in this context cannot be underestimated. ${ }^{3}$

By virtue of its control over Tibet, China has gained proximity to India's Northeast and Siliguri corridor. Nepal is already following a pro Chinese policy since June 2010 by intensifying patrolling along its border areas with China and not only detaining Tibetan refugees but also handing them back to Chinese authorities. With access to Chumbi Valley, China also gets closer to Bangladesh since it is only a narrow strip of land that separates the country from Bhutan. China has already started a policy of enhancing connectivity through a road and railway network laid out in a functional manner. According to sources, there have been indications of Chinese flurry of road, rail and airport building activities all around Tibet to enhance its connectivity with the other parts of China as well as with the countries of South Asia. The Chinese state has already completed the construction of six roads near Bhutan, Northeast and Northwest areas. The $1142 \mathrm{~km}$ section between Golmud and Lhasa being a major competitor of the Quighai Tibet Railway is another indicator of China's urge for connectivity. On the whole this infrastructure

was converted into Chinese territory after the Chinese takeover of Tibet. China never accepted the demarcation and this has become a bone of contention in the state of Arunachal in India. For a history of demarcation of and controversy over the McMahon Line: Sahadev Vohra The Northern Frontier of India, (Delhi, Intellectual Publishing House, 1993).

${ }^{1}$ Sreedhar, China becoming a superpower and India's options" in Across the Himalayan Gap. In: An Indian Quest for Understanding China. Edited by Tan Chung, New Delhi: Gyan Publishing House, 1998, 638. http://ignca.nic.in/ks_41065.htm.

${ }^{2}$ Medha Bisht, "Chumbi Valley: Economic Rationale but Strategic Resonance", IDSA Comment, Last modified September 23, 2010. http://www.idsa.in/idsacomments/ChumbiVal leyEconomicRationalebutStrategicResonance_mbisht_230910.

${ }^{3}$ Sino Indian relations are discussed in historical perspectives by Mira Sinha Bhattacharjea in 'Mao Zedong vision: China, the world and India', by Giri Deshinkar, "The Nehru years revisited", in Across the Himalayan Gap: An Indian Quest for the Understanding of China. ed. Tang Chung (New Delhi: Indira Gandhi National Centre for the Arts \& Gyan Publishing House, 1998), and by Swaran Singh in 'Three agreements and Five Principles between India and China', in Across the Himalayan Gap: An Indian Quest for the Understanding of China. ed. Tang Chung ( New Delhi: Indira Gandhi National Centre for the Arts \& Gyan Publishing House, 1998). 
development is creating security threat for India, as Shigatse is just $250 \mathrm{~km}$ from Nathu-la and Yatung just $50 \mathrm{~km}{ }^{1}$

In this backdrop of tense relationships between India and China, the opening of Nathu-la pass for trade is of great significance. Since the late 1970s, efforts were made to increase trade between these two countries. Finally the Nathu-la was opened following numerous bilateral trade agreements in 2000, which coincided with the 'year of friendship' between the two countries. This can be examined from two perspectives. Following many rounds of discussions and trade agreements, border trade through Nathu-la Pass formally resumed on July $6^{\text {th }}, 2006$. Plans were afoot to open borders to both Indian and Chinese citizens and trade marts along the borders were identified. There were ambitious proposals to establish warehouses, custom and banking facilities, transport network, a marketplace and even residential settlements. While on one hand this is definitely a sign of improved relations between the two countries, it is also a kind of India's assertion of the legitimacy of its control on Sikkim.

Initially, the mood was upbeat in Sikkim but this trade is qualitatively different from what trade used to be in the pre-1962 years. Everything, including the business hours and items of this trade, were worked out beforehand and were to remain under strict Government surveillance. Yet, actual trade failed to take off as it remained limited both in terms of numbers of tradable items as well as their volumes. Trade increased from INR 2 million in 2006 to a meager INR 9.85 million with zero imports in 2010. It also failed to boost the local economy as it was expected to do. ${ }^{2}$ There were complaints on the Chinese side of a certain degree of apathy or even trade sabotage on the part of India. Hao Peng, Vice Chairman of the Tibetan Autonomous Region stated that 'India has unilaterally imposed restrictions on trade through Nathula. Hao also said that India authorized the export of only 29 items from India to China. Similarly, he claimed that while Indian businessmen could stay overnight at the Renqinggang mart on the Tibetan side of Nathu-la, Chinese traders were denied a similar facility at the Indian trading post at Changgu. The official went on to say that trade at Renqinggang mart is currently less than 100,000 yuan (U.S. \$12,500) per week, far less than we had expected". 3

Due to several geo-strategic and security issues, the Indo Chinese trade through Nathu-la has actually failed to take off. Further liberalization of trade could also give China the scope to fulfill its logistic benefits and territorial ambition not only in India but in South Asia as a whole by enhancing its proximity and trans-border trade with Bangladesh, Bhutan and Nepal. Even the Tibetan region of China would be able to avail the facilities of Kolkata port and it would be easier and cheaper to travel to the eastern region of China from

\footnotetext{
${ }^{1}$ Jabin T.Jacob, "The Qinghai Tibet Railway and Nathu-La - Challenge and Opportunity for India." China Report 43, no1 (2007): 83-87

2"Nathula trade closes for this year", I Sikkim My state, My Views. Last Modified December 2, 2010. http://isikkim.com/nathula-trade-closes-for-this-year/.

${ }^{3}$ Quoted by Jabin T. Jacob in 'The Qinghai Tibet Railway and Nathu-La - Challenge and Opportunity for India.” China Report 43, no1 (2007): 83-87.
} 
Tibet. ${ }^{1}$ Shaping India's response to the Chumbi Valley would perhaps require a penetrating understanding of the 'reality' that defines China's trajectory in South Asia in coming years.

In view of the growing number of border violations and frictions between the two sides, the situation calls for an overall strengthening of India's defense preparedness in the region. This can be achieved not only through infrastructure construction but also by engaging Bhutan as a strategic partner.

With Nepal having already taken a pro- Chinese stand, India cannot afford to lose Bhutan as a partner in its foreign policy option. There have been suggestions that in order to achieve that India should also maximize its soft power approach. In this context, the Indian state should take the initiative to establish an environment capable of inspiring and promoting lucrative bilateral relationships with Bhutan. In order to achieve this, Buddhism should be encouraged to flourish in Sikkim so that the commonalities between Bhutan and this region of India are highlighted and cultural exchanges are encouraged. In other words, the situation calls for an overall review of India's foreign policy in this region. Perhaps this explains why the border trade from Nathu-la is kept under control at the moment.

\section{Conclusion}

Chumbi Valley of Tibet is one of those geographical corridors that have enhanced connectivity between the different parts of Asia. In this case it has been the route through which migration has taken place from Tibet to Sikkim and to some extent to Bhutan as well. The politics and culture of these Himalayan states have been shaped by these interactions with Tibet and geopolitics has certainly shaped the cultural diversity of the region. Yet the route gradually assumed a different economic and political significance when in course of the 20th century the British rulers of India, out of their economic interests and imperial ambitions got involved in the great game over Tibet with their probable political adversaries - the Chinese and the Russians. Chumbi became the stage where the British ambition to open up Tibet was played out. Through it passed the expedition of 1903-4 that finally lifted the curtain from the forbidden land of Tibet. Within the context of a constantly changing political scenario of the region, Chumbi Valley has now become the gateway of possible Chinese expansion beyond the Himalayas in South Asia. The Valley, by virtue of its strategic location is now the point where the two great Asian powers of China and India face each other in a war of nerves. The Valley has become one of the most fortified and secured zones in the Himalayan belt.

In conclusion, the history and politics of the region passed through various phases, symbolising the historical transformation of the Tibetan region as a whole. Currently belonging to China, the Chumbi Valley has transformed from a little trodden path in the Tibetan plateau to a high security zone. From being a region of geopolitical significance, where the combination of geographic and

${ }^{1}$ Ibid. 
political factors determined the social, economic and political characteristics of the neighboring states through migration and trade, it has assumed an additional geostrategic significance over the years under the ever changing political situation. Geopolitics now merges with strategic considerations involving comprehensive planning for securing the national military and political interests of both China and India in the region.

\section{Bibliography}

Bisht, Medha. "Chumbi Valley: Economic Rationale but Strategic Resonance", IDSA Comment, Last modified September 23, 2010.http://www.idsa.in/idsacomments/ ChumbiValleyEconomicRationale butStrategicResonance mbisht 230910.

Chung, Tang. Across the Himalayan Gap: An Indian Quest for the Understanding of China, New Delhi: Indira Gandhi National Centre for the Arts \& Gyan Publishing House, 1998. Also available at http://ignca.nic.in/ks_41065.htm.

Deshinkar, Giri . 'The Nehru years revisited'. In Across the Himalayan Gap: An Indian Quest for the Understanding of China. Edited by Tang Chung. New Delhi: Indira Gandhi National Centre for the Arts \& Gyan Publishing House, 1998.

Fader, H. Louis. Called from obscurity: The life and times of a true son of Tibet, God's humble son from Poo: Gergen Dorje Tharchin, v. 1, 2, 3, Kalimpong: Tibet Mirror Press, 2004.

Jacob, Jabin T. "The Qinghai Tibet Railway and Nathu-La - Challenge and Opportunity for India." China Report 43, no1 (2007): 83-87.

Macdonald, David. Touring in Sikkim and Bhutan. Kalimpong: Thackef \&Spink, 1933.

Moktan, R. Sikkim: Darjeeling: Compendium of Documents. Kalimpong: Sumaralaya, 2004.

Nakane, Chie. "A plural society in Sikkim: A study of the interrelations of Lepchas, Bhutias and Nepalis" In Caste and kin in Nepal, India and Ceylon, Anthropological studies in Hindu Buddhist contact zones, Edited by Christoph Von Furer Haimendorf. Delhi: Asia Publishing House, 1966.

"Nathula trade closes for this year", I Sikkim My state, My Views. Last Modified December 2, 2010. http://isikkim.com/nathula-trade-closes-for-this-year/.

O'Brien, R.D. Darjeeling: The Sanatorium of Bengal and its Surroundings. Calcutta, 1883.

Rennie, David Field. Bhotan and the story of the Dooar War, London: John Murray, 1866.

Risley, H.H. The Gazetteer of Sikkim. Calcutta: Bengal Press, 1894. (Reprinted, Delhi: Low Price Publications, 1999).

Rose, Leo. Politics of Bhutan, Ithaca: Cornell University Press, 1970.

Sinha, A C. "Train to Chumbi Valley", On Occasions. Last modified December 27, 2004. http://acoomarsinha.blogspot.in/2004/12/train-to-chumbi-valley.html.

Singh, Swaran. "Three agreements and Five Principles between India and China". In Across the Himalayan Gap: An Indian Quest for the Understanding of China. Edited by Tang Chung. New Delhi: Indira Gandhi National Centre for the Arts \& Gyan Publishing House, 1998.

Sreedhar, "China becoming a superpower and India's options" In Across the Himalayan Gap: An Indian Quest for the Understanding of China. Edited by 
Tang Chung. New Delhi: Indira Gandhi National Centre for the Arts \& Gyan Publishing House, 1998.

Vohra, Sahadev. The Northern Frontier of India. Delhi: Intellectual Publishing House, 1993.

Wangchuk, Pema. "India, China and the Nathu La, Converting Symbolism into Reality." Institute of Peace and Conflict Studies (IPCS) 202, (January 2013), http://www.ipcs.org/pdf_file/issue/IB202-CRP-Pema-NathuLa.pdf.

Warikoo, K. Himalayan Frontiers of India: Historical, geo political and strategic perspectives. London: Routledge, 2009.

Younghusband, Sir Francis. India and Tibet. London: John Murray, 1910. (Reprinted, Delhi: Low Price Publications, 1994). 